\title{
Combination of double negative T cells and anti-thymocyte serum reverses type 1 diabetes in NOD mice
}

\author{
Tianhui Liu ${ }^{1,2+}$, Min Cong ${ }^{1,2 \dagger}$, Guangyong Sun ${ }^{1,2}$, Ping Wang ${ }^{1,3}$, Yue Tian ${ }^{1,2}$, Wen Shi ${ }^{1,2}$, Xinmin Li $i^{1,2}$, Hong You ${ }^{1,2^{*}}$ \\ and Dong Zhang ${ }^{1,2^{*}}$
}

\begin{abstract}
Background: Double-negative (DN) T cells could delay the onset and the progression of autoimmune diabetes, yet they were less efficient on reversing autoimmune diabetes. The aim of this study was to investigate whether the combination of DNT cells and anti-thymocyte serum (ATS) could reverse new-onset diabetes in NOD mice.

Methods: The regulation of different subsets of T cells in vitro and in vivo by ATS and DNT cells were examined using flow cytometry. At the day of diabetes onset, ATS was administered on the same day and 2 days later, and DN T cells were transferred at day 7. The reversion of diabetes was assessed by monitoring blood glucose levels.

Results: The efficacy of inhibition of DN T cells on $C D 8^{+} T$ cells was lower than that on $C D 4^{+} T$ cells both in vitro and in vivo. ATS resulted in a significant depletion of $C D 8^{+} \mathrm{T}$ cells, while DNT cells were less sensitive to ATS depletion. $80 \%$ diabetic NOD mice achieved long term ( 6 months) reversion of diabetes by combined ATS and DNT cells treatment, compared to $16 \%$ in ATS single treatment and none in DN T cell single treatment. DNT cells preferentially resided in spleen and pancreatic draining lymph nodes in ATS plus DNT cells treated NOD mice.
\end{abstract}

Conclusions: DNT cells plus ATS therapy show promising reversion effects on diabetic NOD mice due to a shift of balance from a destructive T cell response to one that favors DN T cell regulation.

Keywords: Cell therapy, $C D 4^{-} \mathrm{CD} 8^{-}$regulatory $T$ cells, Anti-thymocyte serum, NOD mouse, Type 1 diabetes

\section{Background}

Type 1 diabetes is an autoimmune disease in which the patient fails to develop or loses tolerance to self-antigens at a young age. Consequently, auto-aggressive $\mathrm{T}$ cells gradually infiltrate the pancreas and selectively destroy the insulin-producing beta cells, eventually leading to overt diabetes $[1,2]$. Both $\mathrm{CD}_{4}^{+}$and $\mathrm{CD} 8^{+}$cytotoxic $\mathrm{T}$ lymphocytes contribute to beta cell killing [3-5]. One mechanism that may lead to the development of type 1 diabetes is the defective development, activation or function of regulatory $\mathrm{T}$ cells [6-8]. Several subsets of regulatory $\mathrm{T}$ cells have the ability to suppress the proliferation

\footnotetext{
*Correspondence: youhong30@sina.com; zhangd2010@hotmail.com ${ }^{\dagger}$ Tianhui Liu and Min Cong contributed equally to this work

${ }^{1}$ Research Center, Beijing Friendship Hospital, Capital Medical University, 95 Yong-an Road, Xi-Cheng District, Beijing 100050, China

Full list of author information is available at the end of the article
}

and function of autoreactive $\mathrm{T}$ cells and prevent type 1 diabetes development, including naturally occurring and induced populations of $\mathrm{CD} 4{ }^{+} \mathrm{CD} 25^{+} \mathrm{FoxP}^{+} \mathrm{T}$ cells, $\mathrm{CD}^{+}$treg cells, NK $\mathrm{T}$ cells and $\mathrm{CD} 4^{-} \mathrm{CD} 8^{-}$(doublenegative, DN) T cells [9-13]. While currently, it is still a great challenge to reverse new diabetes successfully using adoptive cell therapy.

The DN $\mathrm{T}$ cells that are capable of downregulating the immune response comprise only $1-5 \%$ of $\alpha \beta$ T cell receptor (TCR) + T cells in the peripheral lymphoid tissue of normal mice and humans [14]. DN T cells also play a homeostatic role in autoimmune diabetes. Diabetesprone mice carry fewer DN T cells and this contributes to the increased susceptibility of these mice to developing the disease [15]. Moreover, peptide-activated antigenspecific transgenic DN T cells can prevent autoimmune type 1 diabetes development [12]. DNCD3 splenic T cells 
from young non-obese diabetic (NOD) mice were demonstrated to be able to induce long-lasting protection against diabetes subjected to an adoptive cell transfer protocol [16].

We identified a new differentiation pathway, by which a subset of proliferated $\mathrm{CD} 4^{+} \mathrm{T}$ cells converted to $\mathrm{DN}$ $\mathrm{T}$ cells after antigen-triggered or homeostatic proliferation in vitro and in vivo. Using this novel pathway, tens of millions of DN T cells can be rapidly produced [17]. We also reported that $\mathrm{CD} 4^{+} \mathrm{T}$ cells converted to pancreatic islet beta cell antigen-specific DN T cells can prevent the development of autoimmune diabetes and promote islet allograft survival in NOD mice [13]. Because DN $\mathrm{T}$ cells proliferated at very low levels in vitro and in vivo [17] and DN T cell inhibition on target cells was shown to be dependent on cell-cell contact [18], lymphodepletion treatment to diminish pathogenic $\mathrm{T}$ cells population prior to DN T cell therapy might be an effective method to achieve more profound regulation.

In this study, we investigated the regulation of different subsets of $\mathrm{T}$ cells in vivo and in vitro by anti-thymocyte serum (ATS) and DN T cells. We also report the use of $\mathrm{CD} 4^{+} \mathrm{T}$ cell converted antigen-specific $\mathrm{DN} \mathrm{T}$ cells in combination with ATS to suppress and reverse autoimmune diabetes in NOD mice with newly developed type 1 diabetes.

\section{Methods}

\section{Animals}

Male C57BL/6 $\left(\mathrm{H} 2^{b}\right), \mathrm{C} 57 \mathrm{BL} / 6 \mathrm{RAG}^{-1-}\left(\mathrm{H} 2^{\mathrm{b}}\right), \mathrm{C} 57 \mathrm{BL} / 6$ congenic for $\mathrm{CD} 45.1\left(\mathrm{H} 2^{b}\right), \mathrm{DBA} / 2\left(\mathrm{H}_{2}{ }^{d}\right)$ and female NOD $\left(\mathrm{H} 2^{\circ}\right)$ were purchased from Vital River Laboratories (Beijing, China) and the Jackson Laboratory (Bar Harbor, ME, USA). All mice were maintained in pathogen-free facilities at Beijing Friendship Hospital. All protocols were approved by the Institutional Animal Care and Ethics Committee.

\section{Purification of $\mathrm{CD}^{+}{ }^{+} \mathrm{T}$ cells, $\mathrm{CD}^{+} \mathrm{T}$ cells}

Single-cell suspensions of mouse spleens and lymph nodes were prepared. $\mathrm{CD} 4^{+} \mathrm{T}$ cells were isolated by $\mathrm{T}$ cell enrichment column ( $R$ and D Systems, Minneapolis, MN, USA) followed by Ter119, B220, CD8, CD11b, TCR $\gamma \delta, \mathrm{CD} 25$ and NK1.1 positive cell depletion. $\mathrm{CD}^{+} \mathrm{T}$ cells were isolated by $\mathrm{T}$ cell enrichment column followed by Ter119, B220, CD4, CD11b, TCR $\gamma \delta$ and NK1.1 positive cell depletion.

\section{Conversion of DN T cells in vitro}

Conversion of DN T cells in vitro was performed as previously described [13]. Briefly, mature dendritic cells (mDCs) were harvested from lipopolysaccharide-stimulated bone marrow cells of DBA/2 or NOD mice, and separated by CD86-positive selection. C57BL/6 CD4 ${ }^{+}$ $\mathrm{T}$ cells were incubated with DBA/2 mDCs with $50 \mathrm{ng} /$ $\mathrm{ml}$ rmIL-2 (Peprotech, Rocky Hill, NJ, USA). CD4 ${ }^{+} \mathrm{T}$ cells from NOD mice were cultured with NOD mDCs in the same conditions described above plus the addition of $1 \mu \mathrm{g} / \mathrm{ml}$ GAD65 peptides. $\mathrm{CD}^{+} \mathrm{CD} 4^{-} \mathrm{CD} 8^{-} \mathrm{DN}$ fractions were isolated from mixed lymphocyte reaction (MLR) and sorted using a FACS (AriaII; BD Biosciences, San Diego, CA, USA).

\section{In vitro suppression assays}

Carboxyfluorescein diacetate succinimidyl ester (CFSE; Molecular Probes, Eugene, OR, USA) labeled $\mathrm{CD} 44^{+}$ or $\mathrm{CD}^{+} \mathrm{T}$ cells $\left(1 \times 10^{5}\right.$ /well $)$ from CD45.1 congenic C57BL/6 mice were co-cultured with $\mathrm{DBA} / 2 \mathrm{mDCs}$ $\left(0.25 \times 10^{5} /\right.$ well $)$ for 4 days. The same amount of converted B6 DN T cells were added to MLR as regulatory cells. $\mathrm{CD} 4^{+}$and $\mathrm{CD} 8^{+} \mathrm{T}$ cell proliferation was examined by flow cytometry.

\section{ATS treatment in vitro}

For ATS treatment of mouse splenocytes, freshly isolated cells were cultured in complete medium with $2 \mu \mathrm{l} / \mathrm{ml}$ of either ATS or rabbit serum (Accurate Chemical and Scientific Corporation, Westbury, NY, USA). Twenty-four hours following culture initiation, splenocytes were harvested and TCR $-\beta^{+}, \mathrm{CD} 4^{+}, \mathrm{CD} 8^{+} \mathrm{T}$ and $\mathrm{DN} \mathrm{T}$ cells were examined by flow cytometry.

\section{ATS treatment in vivo}

Eight-week-old NOD mice were treated with two intraperitoneal injections of ATS or rabbit serum $(50 \mu \mathrm{l} /$ mouse) at day 0 and 2 . Mice were monitored continuously by examining TCR- $\beta^{+}, \mathrm{CD} 4^{+}, \mathrm{CD} 8^{+} \mathrm{T}$ and $\mathrm{DN} \mathrm{T}$ cells in peripheral blood monocytes (PBMCs) using flow cytometry.

\section{Adoptive transfer and skin transplantation}

C57BL/6 DN T cells $\left(1 \times 10^{5}\right)$ in combination with $1 \times 10^{5}$ naive $\mathrm{CD} 4^{+} \mathrm{CD} 25^{-} \mathrm{T}$ cells or $\mathrm{CD}^{+} \mathrm{T}$ cells were transferred to $\mathrm{C} 57 \mathrm{BL} / 6 \mathrm{RAG}^{-1-}$ mice by tail vein injection. On the same day, full thickness $1 \mathrm{~cm}^{2}$ tail skin grafts from DBA/2 mice were transplanted to the C57BL/6 $\mathrm{RAG}^{-1-}$ mice. Graft survival was monitored by daily visual inspection. Graft rejection was defined as complete necrosis and loss of viable skin tissue.

\section{Adoptive transfer and diabetes reversion}

Mice were monitored for diabetes development by measuring blood glucose levels twice weekly. Diabetes onset was defined as blood glucose levels of $>12 \mathrm{mmol} / \mathrm{L}$ in two consecutive measurements. In the event of new-onset diabetes, two doses of $50 \mu \mathrm{l}$ ATS were given to diabetic 
NOD mice on day 0 and 2 by intraperitoneal injection. On day 7, ex vivo converted GAD65 primed DN T cells $\left(1 \times 10^{6}\right)$ were transferred to ATS-treated mice by tail vein injection. Blood glucose levels of treated mice were inspected every other day.

\section{Flow cytometric analysis}

Cultured cells or PBMCs from treated mice were harvested at various time points and analyzed for proliferation or the expression of various cell surface markers. All samples were analyzed on an Aria II flow cytometer (BD Biosciences). Data was analyzed using FlowJo software (Treestar; FlowJo, Ashland, OR, USA).

\section{Histologic examination}

Pancreas were isolated 4 weeks after diabetes onset, and were fixed in $4 \%$ paraformaldehyde, paraffin embedded, and sectioned. $\mathrm{H}$ and $\mathrm{E}$ staining was performed.

\section{Statistical analysis}

Analyses for statistically significant difference were performed using the Student's $t$ test and one-way ANOVA test. The effects of DN T cells on diabetes reversion in the adoptive transferred models and the skin transplant model were statistically analyzed using a log-rank test. $p$ values $<0.05$ were considered significant.

\section{Results}

$\mathrm{CD}^{+} \mathrm{T}$ cells converted DN T cells showed strong immune regulation on $\mathrm{CD}^{+} \mathrm{T}$ cells, but less suppression on $\mathrm{CD}^{+} \mathrm{T}$ cells both in vitro and in vivo

As shown in Fig. 1a, C57BL/6 DN T cells that were incubated with mature $\mathrm{DBA} / 2 \mathrm{mDCs}$ in vitro potently suppressed C57BL/6 (CD45.1) $\mathrm{CD}^{+}$and $\mathrm{CD} 8^{+} \mathrm{T}$ cell proliferation triggered by the same alloantigens (DBA/2 $\mathrm{DCs})$ in vitro. The inhibition efficacy of DN T cells on $\mathrm{CD}^{+} \mathrm{T}$ cells $(46.2 \%)$ was lower than that on $\mathrm{CD}^{+} \mathrm{T}$ cells $(67.7 \%)$ (Fig. 1b). The differences were more profound in vivo. Compared with control, significant prolongation of skin allograft survival on $\mathrm{RAG}^{-/-}$recipients occurred when equal numbers of $\mathrm{DN} \mathrm{T}$ cells and $\mathrm{CD} 4{ }^{+} \mathrm{CD} 25^{-} \mathrm{T}$ cells were co-transferred (Fig. 1c; mean graft survival time of 28 days vs 20.5 days; $p=0.0114$ ). In contrast, DN T cells did not protect the skin graft rejection triggered by $\mathrm{CD}^{+} \mathrm{T}$ cells (Fig. $1 \mathrm{~d} ; p=0.2857$ ).

\section{ATS treatment preferentially depleted $\mathrm{CD} 8^{+} \mathrm{T}$ cells while DN T cells were resistant to ATS both in vitro and in vivo}

Both anti-thymocyte globulin (ATG) and ATS therapy can largely eliminate $\mathrm{T}$ cells from peripheral blood. It is debated whether ATG therapy preferentially depletes certain subsets of $\mathrm{T}$ cells. For instance, Xia et al. [19] have reported that ATG depletes $\mathrm{CD}^{+} \mathrm{T}$ cells more efficiently than $\mathrm{CD}^{+} \mathrm{T}$ cells in both peripheral blood and lymphoid organs. We investigated changes of the absolute numbers and percentages of different $\mathrm{T}$ cell subsets in vitro. As shown in Fig. 2a, the percentage of $\mathrm{CD}^{+}{ }^{+} \mathrm{TCR}-\beta^{+}$cells in splenocytes decreased from 44.7 to $25.4 \%$ with ATS treatment, and the absolute number of $\mathrm{CD}^{+}$TCR- $\beta^{+}$cells also decreased significantly (Fig. 2b). The relative percentage of $\mathrm{CD} 4^{+} \mathrm{T}$ cells among the $\mathrm{CD}^{+} \mathrm{TCR}-\beta^{+}$lymphocytes changed from 65.2 to $80.2 \%$, while $\mathrm{CD}^{+} \mathrm{T}$ cells $(27.8-0.31 \%)$ was almost eliminated by ATS treatment (Fig. 2a). Both absolute number of $\mathrm{CD} 4^{+}$and $\mathrm{CD} 8^{+} \mathrm{T}$ cells decreased, compared to $\mathrm{CD}^{+} \mathrm{T}$ cells, the absolute number of $\mathrm{CD}^{+} \mathrm{T}$ cells was more significantly decreased post-ATS treatment (Fig. 2c). Compared to the rabbit serum group, among all of the $\mathrm{CD} 3^{+} \mathrm{TCR}-\beta^{+}$lymphocytes, the ATS group demonstrated a significantly increased percentage (6.2119 \%) (Fig. 2a) and a similar absolute number of DN T cells (Fig. 2c), suggesting that DN T cells were resistant to ATS mediated depletion.

We monitored the post-ATS treatment depletion of different subsets of T cells in vivo. NOD mice were treated with two doses of ATS or rabbit serum (day 0 and 2), the percentages of different $\mathrm{T}$ cell subsets in the peripheral blood were examined (Fig. 3a). After treatment, we drew blood from each group $(n=4)$ on the day indicated in Fig. 3b-e. As shown in Fig. 3b, after ATS treatment, the TCR $-\beta^{+}$T cells in the peripheral blood were nearly depleted on day 3 (from 30 to $0.03 \%$ ), but began to recover on day 12 and were still lower on day $30 \mathrm{com}$ paring with the rabbit serum group. As shown in Fig. 3c, after ATS treatment, the $\mathrm{CD} 4^{+} \mathrm{T}$ cell percentage of the total TCR $-\beta^{+}$T cell pool dropped to its lowest level on day 3 (from 60 to $25 \%$ ), and began to recover afterwards and returned to a normal percentage of TCR- $\beta^{+}$T cell by day 12 . Compared to the rabbit serum group, the $\mathrm{CD} 8^{+}$ $\mathrm{T}$ cells dropped to their lowest levels in total TCR- $\beta^{+} \mathrm{T}$ cells 5 days after ATS therapy (from 40 to $5 \%$ ). The relative percentage of $\mathrm{CD}^{+} \mathrm{T}$ cells began to recover slowly after day 5 , and remained significantly lower than the control group on day 30 (Fig. 3d). Interestingly, the proportionate increase of $\mathrm{DN} T$ cells relative to the total TCR- $\beta^{+}$T cells (Fig. 3e) was found in ATS group on day 1 and reached its peak on day 4 post-treatment.

The data above demonstrated that ATS strongly regulates $\mathrm{TCR}-\beta^{+}, \mathrm{CD} 4^{+}$and $\mathrm{CD} 8^{+} \mathrm{T}$ cells both in vitro and in vivo. The most profound inhibition efficacy was observed against $\mathrm{CD} 8^{+} \mathrm{T}$ cells. In contrast, the in vitro and in vivo data showed that DN T cells were resistant to ATS mediated depletion. 
a

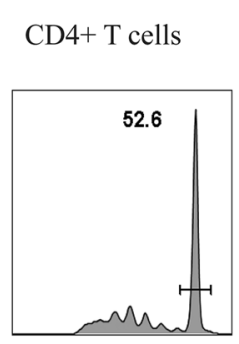

CD8+ T cells

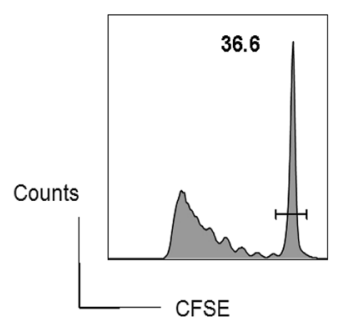

CD4+ T cell + DN T cells

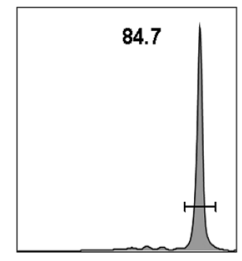

CD8+ T cell

+ DN T cells

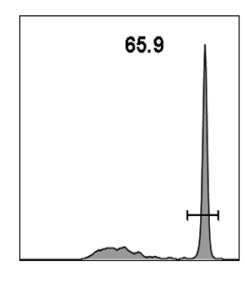

b

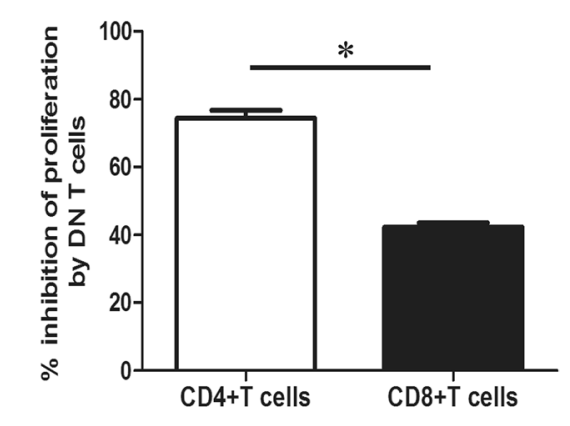

c

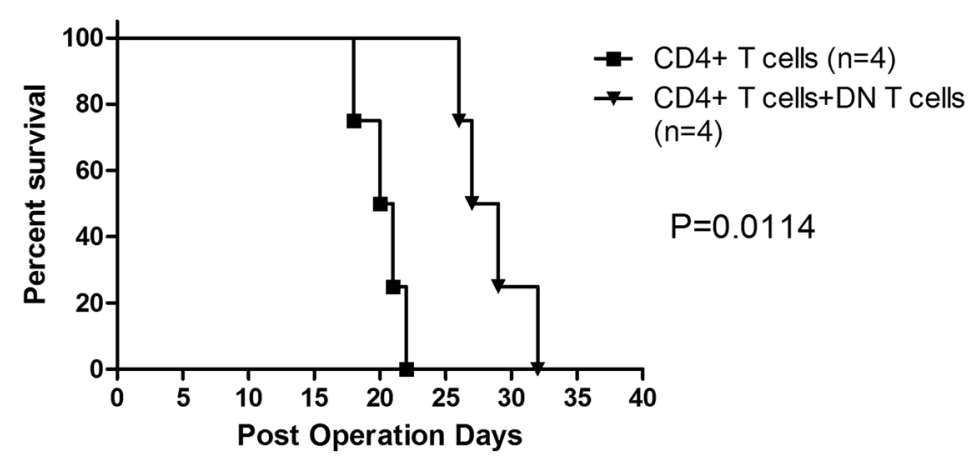

d

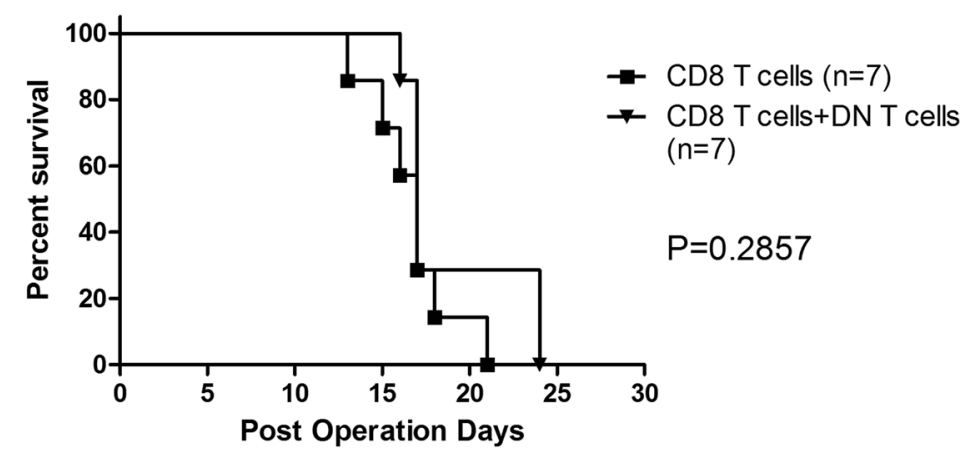

Fig. 1 DNT cells showed different immune regulation of CD4 $4^{+}$and $C D 8^{+}$T cells in vitro and in vivo. a DNT cells potently suppressed CFSE-labeled $\mathrm{CD}^{+}$and $\mathrm{CD} 8^{+} \mathrm{T}$ cell proliferation triggered by $\mathrm{mDC}$ in vitro. The horizontal bars gate the un-dividing cells, and the numbers refer to the percentages these cells comprise of the total $\mathrm{CD}^{+}$or $\mathrm{CD}^{+} T$ cells respectively. $\mathbf{b}$ The data are shown as percent inhibition of proliferation compared with controls, to which no DNT cells were added. The results reported are representative of three experiments with similar results. c The rejection of a skin graft from DBA/2 mice transplanted to C57BL/6 RAG ${ }^{-/}$mice was induced by adoptive transfer of naïve C57BL/6 CD4 $4^{+} \mathrm{CD} 25^{-} \mathrm{T}_{\mathrm{cells}}$ or CD8 ${ }^{+}$ T cells. C57BL/6 DN T cells were co-transferred by tail vein injection. Graft survival was observed by daily visual inspection. DN T cells suppressed naïve $C D 4^{+} C D 25^{-} T$ cell-triggered skin allograft rejection. $\mathbf{d}$ DN T cells failed to prolong naïve $C D 8^{+} T$ cell-triggered skin allograft rejection. Statistical analysis was performed using a log-rank test 


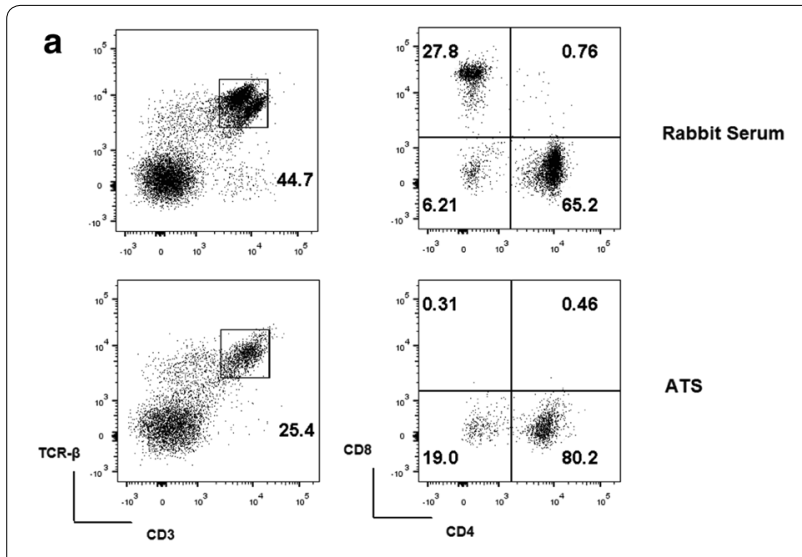

b

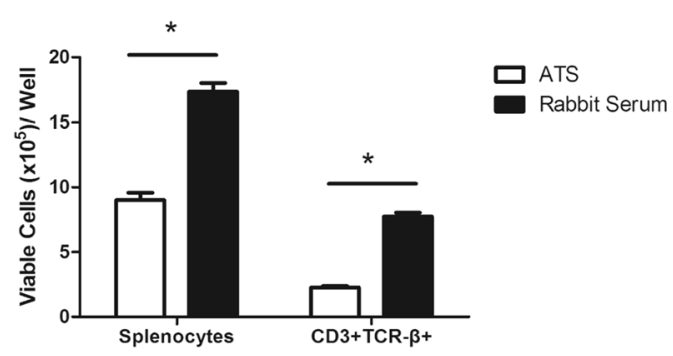

C

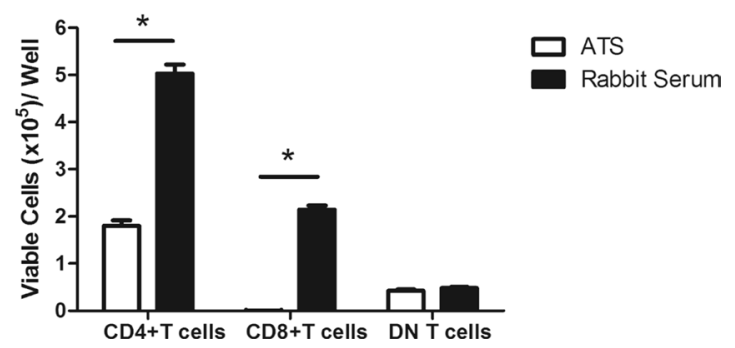

Fig. 2 ATS treatment differentially depletes $T$ cells from spleen after $24 \mathrm{~h}$ in vitro. C57BL/6 splenocytes were cultured with $2 \mu \mathrm{l} / \mathrm{ml}$ ATS or rabbit serum and $\mathbf{a}$ the percentage of TCR- $\beta^{+}, \mathrm{CD} 4^{+}, \mathrm{CD}^{+}$and DN $T$ cells were evaluated $24 \mathrm{~h}$ later by flow cytometry. The numbers in the left panels refer to the percentages of $\mathrm{CD} 3^{+} \mathrm{TCR}-\beta^{+}$cells in the total lymphocyte pool, the numbers in the right panels refer to the percentages of $\mathrm{CD}^{+}{ }^{+}, \mathrm{CD}^{+}$and $\mathrm{DN} T$ cells among the $\mathrm{CD} 3^{+} \mathrm{TCR}-\beta^{+}$ lymphocytes. Data are representative of three experiments performed with similar results. b Absolute numbers of splenocytes and CD $3^{+}$TCR- $\beta^{+}$T cells $24 \mathrm{~h}$ following the initiation of the cultures. $\mathbf{c}$ Absolute numbers of $\mathrm{CD}^{+}{ }^{+}, \mathrm{CD}^{+}$and DN T cells $24 \mathrm{~h}$ following the initiation of the cultures. Data shown are the means ( \pm standard deviation [SD]) of three separate experiments

\section{Combined ATS and DN T cell treatment resulted} in significant reversion of new-onset autoimmune diabetes in NOD mice

DN $\mathrm{T}$ cells did not efficiently suppress $\mathrm{CD}^{+} \mathrm{T}$ cells in vivo, while ATS significantly depleted $\mathrm{CD}^{+} \mathrm{T}$ cells but had no strong effects on DN T cells. We therefore explored whether the combination of ATS treatment with $\mathrm{CD}^{+}{ }^{+} \mathrm{T}$ cell converted DN T cells could reverse new onset type 1 diabetes in NOD mice. Two doses of ATS were given to diabetic NOD mice on day 0 and day 2 after diabetes onset by intraperitoneal injection. On day 7, $1 \times 10^{6}$ ex vivo GAD65 primed DN T cells were transferred to the ATS treated mice by tail vein injection.

Twenty-one days after diabetes onset, $80 \%$ of the diabetic NOD mice $(n=6)$ that received the combined ATS and DN $\mathrm{T}$ cell treatment achieved autoimmune diabetes reversion that lasted for at least 6 months (Fig. 4A). In contrast, a single transfer of an equivalent amount of GAD65 primed DN T cells was unable to induce reversion of hyperglycemia in any recipient $(n=5)$. ATS induction therapy alone $(n=12)$ resulted in a $16 \%$ reversion of hyperglycemia in all recipients. These data suggest that ATS induction therapy significantly promotes DN T cell efficacy in reversing autoimmune diabetes.

Histopathological changes were assessed in $\mathrm{H}$ and E-stained pancreas sections from NOD recipients 28 days after diabetes onset in each group (Fig. 4B). A massive mononuclear cells infiltration of the islets with loss of islet structure was observed in the no treatment group (a). Fewer mononuclear cells infiltration of the islets were observed in diabetic NOD mice that received either ATS or $1 \times 10^{6} \mathrm{DN}$ T cells alone (b and c). In contrast, pancreas sections from NOD mice given $1 \times 10^{6}$ DN $\mathrm{T}$ cells in combination with ATS treatment (d) showed normal islet structure without obvious mononuclear cell infiltration.

\section{After combined ATS plus DN T cell treatment in NOD mice, the percentage of DNT cells in spleen and pancreatic draining lymph nodes (LN) is significantly higher than that in mesenteric LN}

To gain further understanding of the distribution of DN $\mathrm{T}$ cells in diabetic NOD mice cured by combined ATS plus DN T cell treatment, we investigated the percentage of DN T cells in different peripheral lymphoid tissues. As indicated in Fig. 5, the percentage of DN T cells in spleen and pancreatic draining lymph nodes (LN) is relatively higher in all groups than in mesenteric LN. Six months after combined ATS and DN T cell treatment, the percentage of DN T cells (10.4\% in draining LN, $16.8 \%$ in the spleen) is higher in treated mice than in diabetes free control (7.25\% in draining LN, $7.64 \%$ in the spleen) or diabetic NOD mice that received no treatment $(6.35 \%$ in draining LN, $8.61 \%$ in the spleen). Compared with diabetes free control or diabetic NOD mice that received no treatment, in the combined treatment group, the percentage of DN T cells in draining $\mathrm{LN}$ (10.4\%) and the spleen $(16.8 \%)$ is significantly higher than the percentage in mesenteric LN (4.79\%). Additionally, the suppression of $\mathrm{CD}^{+} \mathrm{T}$ cells in spleen is still significant 6 months after 


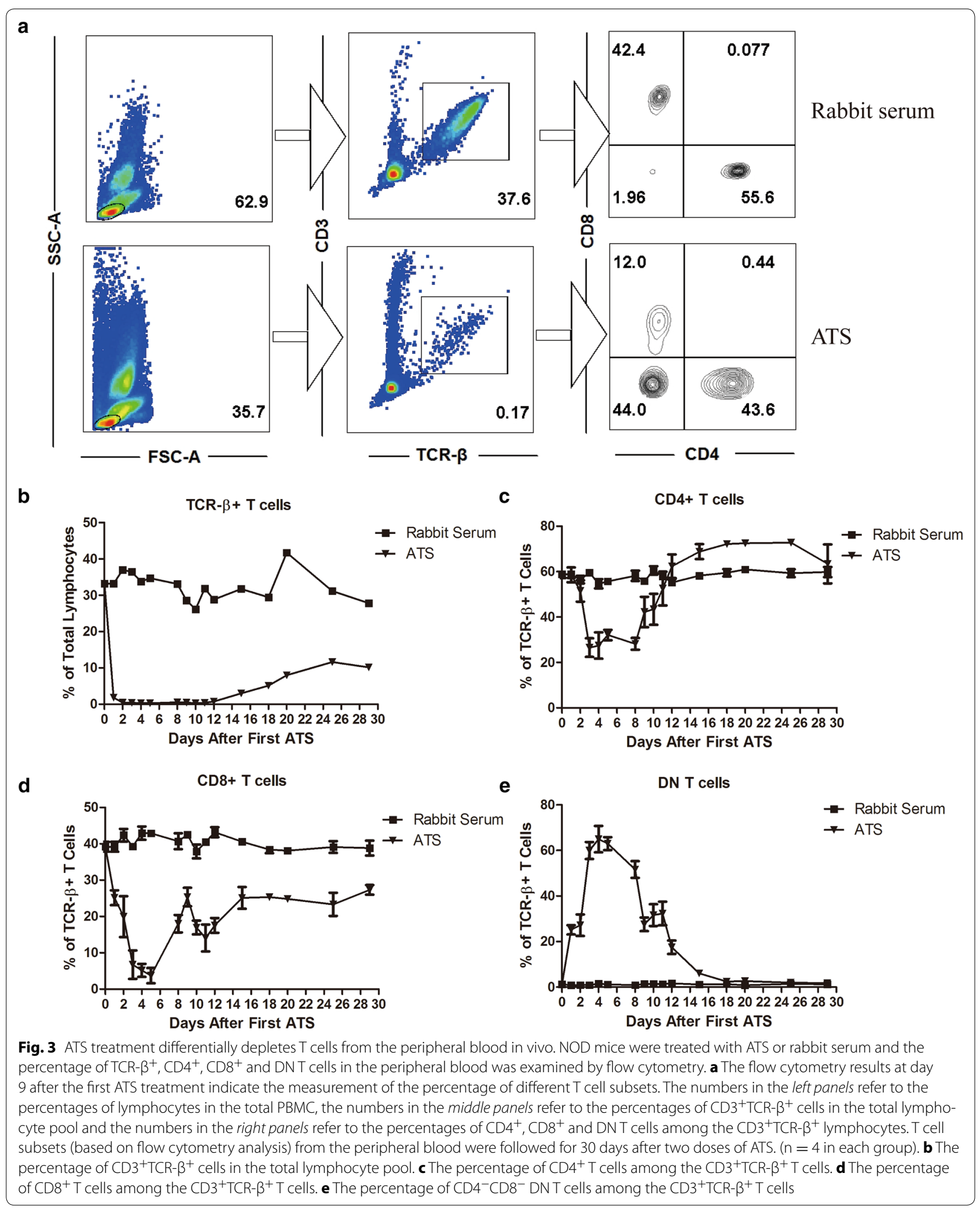




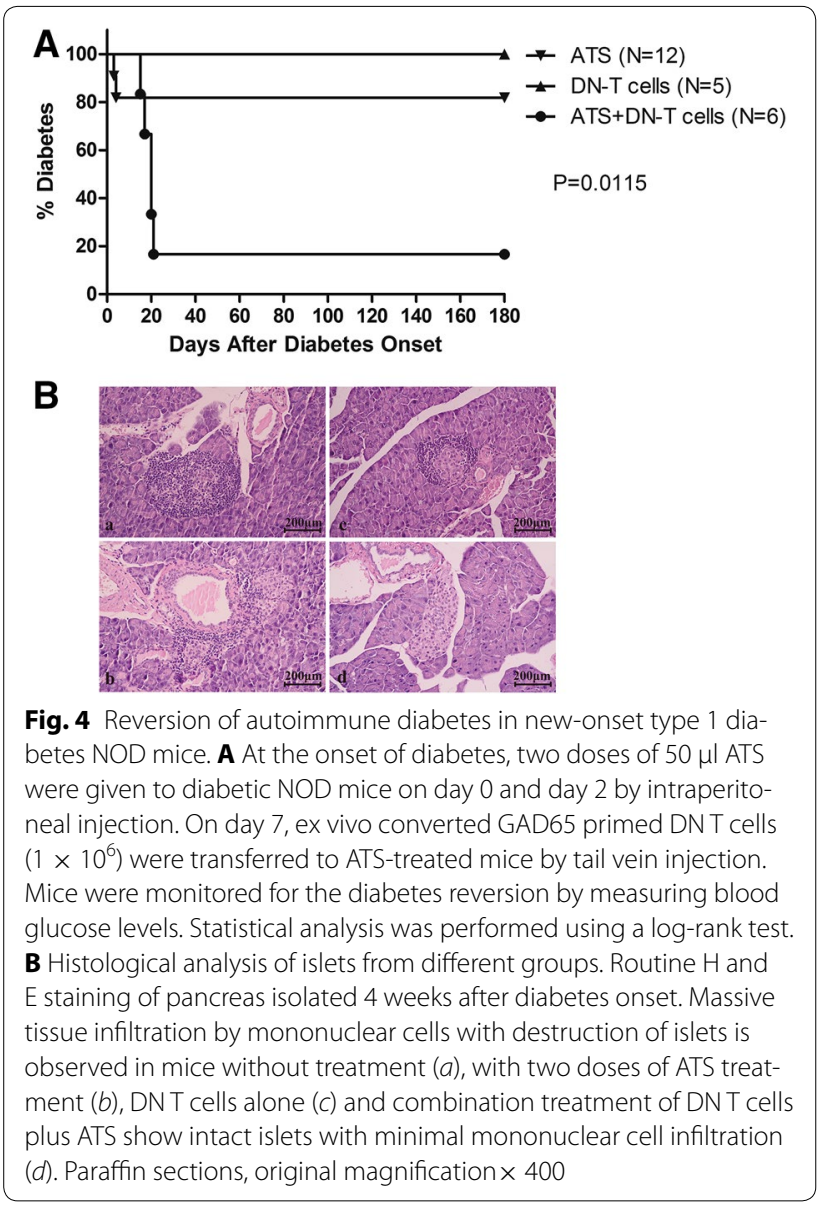

treatment. This suggests that combined treatment leads to long-term suppression of $\mathrm{CD}^{+} \mathrm{T}$ cells.

\section{Discussion}

Type 1 diabetes develops when the insulin-secreting beta cells are destroyed by infiltrating $\mathrm{T}$ cells. Autoreactive $\mathrm{T}$ cells, both $\mathrm{CD}^{+}$and $\mathrm{CD}^{+}$cells, have been implicated as active players in beta-cell destruction $[2-5,20]$. Thus, a treatment strategy that targets both $\mathrm{CD}^{+}$as well as $\mathrm{CD}^{+} \mathrm{T}$ cells may be able to induce immunological tolerance to beta cells.

Studies reveal that DN T cells are potent $\mathrm{T}$ cells suppressors $[15,21,22]$. We previously demonstrated that $\mathrm{CD} 4^{+} \mathrm{T}$ cell converted DN T cells blocked autoimmunity and prevented diabetic onset in NOD mouse models. These effects were even greater when using islet beta cell antigen-specific DN T cells. However, reversing newonset autoimmune diabetes was a more daunting challenge. A single transfer of $4 \times 10^{6} \mathrm{DN} \mathrm{T}$ cells only slightly postponed the progression of hyperglycemia in newonset autoimmune diabetic mice [13]. In this study, the efficacy of inhibition of DN T cells on $\mathrm{CD}^{+} \mathrm{T}$ cells was lower than on $\mathrm{CD}^{+} \mathrm{T}$ cells in vitro. Furthermore, the cotransfer of DN T cells did not protect against $\mathrm{CD}^{+} \mathrm{T}$ cell triggered skin graft rejection. These results indicate that inefficient $\mathrm{CD} 8^{+} \mathrm{T}$ cells suppression in vivo may be one of the reasons underlying the failure of $\mathrm{DN} \mathrm{T}$ cells to control autoimmunity in new-onset diabetic NOD mice. The failure of these trials has led to efforts to more directly shift the balance from destructive a $\mathrm{T}$ cell response to regulatory $\mathrm{T}$ cell control [23].

ATG is a common immunosuppressive reagent used in allogeneic transplantation [24-26] and autoimmune disorders [27-31]. ATS is a polyclonal rabbit anti-mouse thymocyte product that is similar in action to ATG and that effectively depletes peripheral blood $\mathrm{T}$ cells in vivo [32]. Spontaneous diabetes in female mice was suppressed by ATS [33]. ATG therapy functions through complement mediated depletion of mature $\mathrm{T}$ cells, while tregs were less sensitive to ATG depletion [19]. However, researchers found that a brief course of ATG therapy does not result in the preservation of $\beta$-cell function 12 months after the treatment course in patients with new-onset type 1 diabetes [34]. Furthermore, ATG does not reverse type 1 diabetes in the acute virally induced rat insulin promoter-lymphocytic choriomeningitis virus (RIP-LCMV) model [35].

In line with previous reports, we found that ATS therapy markedly depleted TCR- $\beta^{+}, \mathrm{CD} 4^{+}$and $\mathrm{CD} 8^{+} \mathrm{T}$ cells. Among these cell types, $\mathrm{CD} 8^{+} \mathrm{T}$ cells were the most sensitive to ATS depletion. We report, for the first time, that DN T cells are, like Tregs, less sensitive to ATS depletion and make up a dramatically increased percentage of the post-treatment cell population. These results could explain why ATS induction therapy resulted in a $16 \%$ reversion of hyperglycemia in new-onset diabetic NOD mice.

Our data suggest that ATS markedly suppresses $\mathrm{CD} 8^{+} \mathrm{T}$ cells and selectively preserves the DN T cell population. We also demonstrated that converted DN $\mathrm{T}$ cells have a strong ability to regulate pathogenic $\mathrm{CD} 4^{+} \mathrm{T}$ cells but a lesser ability to suppress $\mathrm{CD} 8^{+} \mathrm{T}$ cells. We then assessed the ability of combined ATS induction and DN T cell therapy to shift the balance away from a destructive $\mathrm{T}$ cell response towards a $\mathrm{DN} \mathrm{T}$ cell regulated response in new-onset diabetic mice. After the ATS treatment has reduced the levels of both $\mathrm{CD}^{+}$and $\mathrm{CD}^{+}{ }^{+} \mathrm{T}$ cells, GAD65 primed DN T cells that were converted from $\mathrm{CD} 4^{+} \mathrm{T}$ cells in vitro were transferred 7 days after diabetes onset. In 21 days, the combined treatment achieved long term reversion of autoimmune diabetes in most of the new-onset diabetic NOD mice (80\%). However, an equivalent amount of GAD65-primed DN T cells resulted in no reversal of hyperglycemia. When used alone to treat new-onset diabetic NOD mice, ATS induction only resulted in a $16 \%$ reversion of hyperglycemia. 


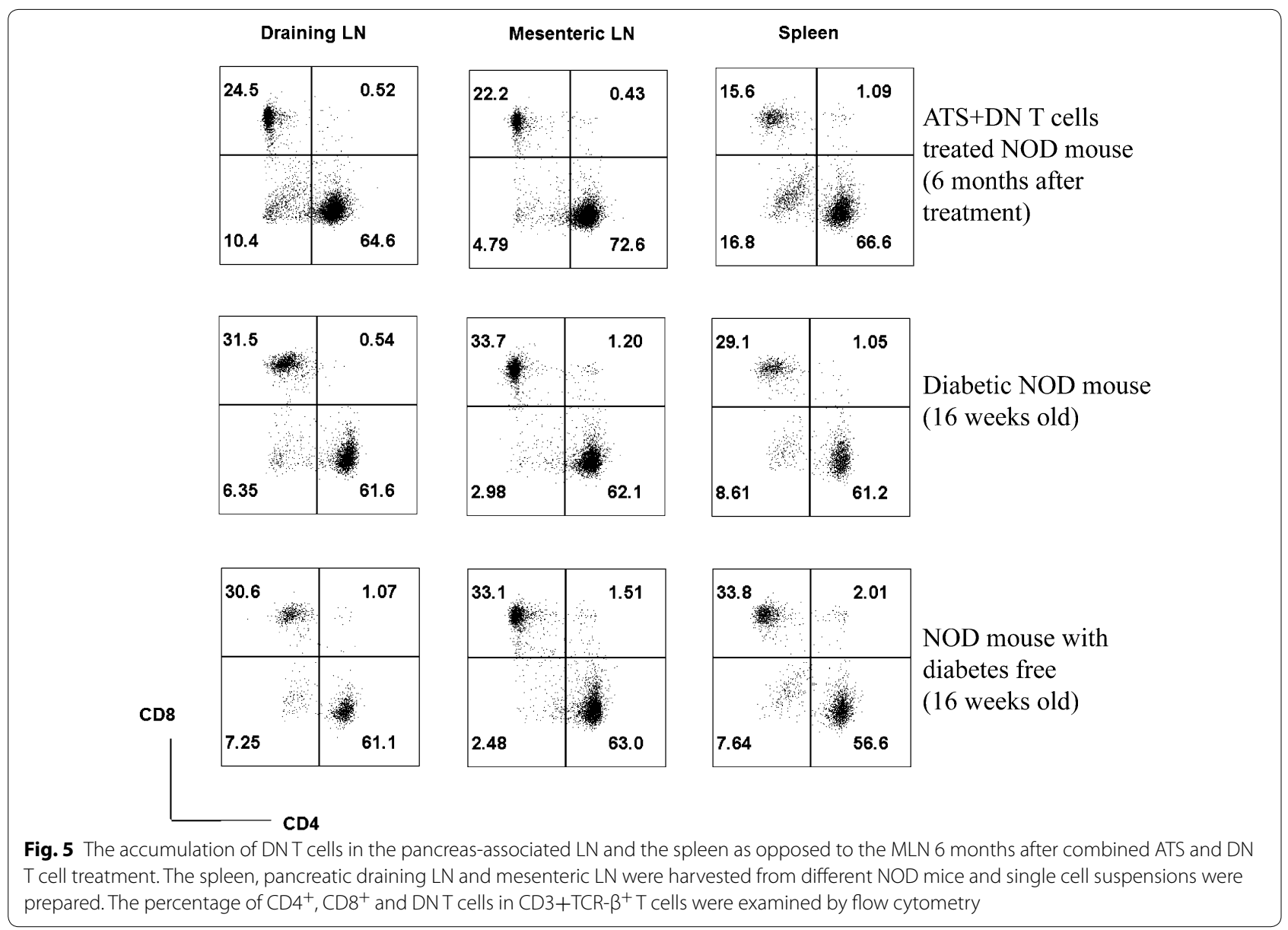

Treg homing in secondary lymphoid tissues is required for the functional clustering of tregs with APCs and T cells that is necessary for the induction and maintenance of immunological tolerance [36, 37]. We first report that DN $\mathrm{T}$ cells preferentially migrate to the spleen and pancreatic draining LN. Six months after ATS plus DN T cell treatment, the percentage of $\mathrm{DN} T$ cells in mice receiving the combined treatment is higher than that observed in both diabetes free mice and diabetic NOD mice without treatment. In the combined treatment group, the percentage of DN T cells in draining $\mathrm{LN}$ and the spleen is significantly higher than that found in mesenteric LN. This indicates that islet specific DN T cells migrated to the pancreatic draining LN and spleen and protected the islets' beta cells from destruction by pathogenic $\mathrm{T}$ cells, but that $\mathrm{DN} T$ cells did not migrate to other unrelated lymphoid organs. Additionally, combined treatment induced long-term suppression of $\mathrm{CD}^{+} \mathrm{T}$ cells. Taking into consideration the major role that $\mathrm{CD}^{+} \mathrm{T}$ cells play in autoimmune diabetes, the potent and long-term suppression of $\mathrm{CD}^{+} \mathrm{T}$ cells by $\mathrm{DN}$ $\mathrm{T}$ cells is likely one of the reasons for the long-term reversion of diabetes caused by the combined treatment.

\section{Conclusions}

The combination of transient $\mathrm{T}$ cell depletion by ATS with adoptive transfer of ex vivo $\mathrm{CD} 4^{+} \mathrm{T}$ cell converted $\mathrm{DN} T$ cells leads to a long term reversal of new-onset diabetes in NOD mice. The improvement of outcome is due to a shift of balance from a destructive $\mathrm{T}$ cell response to one that favors DN $\mathrm{T}$ cell regulation. The results reported by this study support the concept and the potential feasibility of utilizing this novel cell-based therapeutic approach for the treatment of autoimmune type 1 diabetes.

\section{Abbreviations}

DN: double-negative; NOD: non-obese diabetic; ATS: anti-thymocyte serum; TCR: T cell receptor; ATG: anti-thymocyte globulin; LN: Iymph nodes; Tregs: regulatory $T$ cells.

\section{Authors' contributions}

DZ and HY participated in designing the study, analyzing the data, and initiating the original draft of the article. TL and MC participated in performing the research, analyzing the data and initiating the original draft of the article. GS, PW, YT, WS, XL participated in the performance of the research. All authors contributed to the interpretation of the data and revising the draft to produce the final format of the article. All authors read and approved the final manuscript. 


\section{Author details}

${ }^{1}$ Research Center, Beijing Friendship Hospital, Capital Medical University, 95 Yong-an Road, Xi-Cheng District, Beijing 100050, China. ${ }^{2}$ Beijing Key Laboratory of Tolerance Induction and Organ Protection in Transplantation, Beijing, China. ${ }^{3}$ Beijing Key Laboratory of Translational Medicine in Liver Cirrhosis \& National Clinical Research Center of Digestive Diseases, Liver Research Center, Beijing Friendship Hospital, Capital Medical University, Beijing, China.

\section{Acknowledgements}

This work was supported by Grants from the National Natural Science Foundation of China (Nos. 81273271 and 81141107), the Beijing Natural Science Foundation (No. 7,121,006 and 7142043), the Beijing Health System Talents Plan (2013-2-026, 2013-3-062, and 2013-3-057) and the Program for Excellent Talents of Beijing (No. 2011D003034000037).

\section{Competing interests}

None of the authors has any financial interest in any of the products, devices, or drugs mentioned in this manuscript.

\section{Received: 14 July 2015 Accepted: 18 January 2016}

Published online: 24 February 2016

\section{References}

1. Rossini AA, Mordes JP, Like AA. Immunology of insulin-dependent diabetes mellitus. Annu Rev Immunol. 1985;3:289-320.

2. Knip M, Siljander H. Autoimmune mechanisms in type 1 diabetes. Autoimmun Rev. 2008;7:550-7.

3. Onengut-Gumuscu S, Concannon P. Recent advances in the immunogenetics of human type 1 diabetes. Curr Opin Immunol. 2006;18:634-8.

4. Tsai S, Shameli A, Santamaria P. CD8 + T cells in type 1 diabetes. Adv Immunol. 2008:100:79-124.

5. Skowera A, Ellis RJ, Varela-Calvino R, Arif S, Huang GC, Van-Krinks C, Zaremba A, Rackham C, Allen JS, Tree TI, et al. CTLs are targeted to kill beta cells in patients with type 1 diabetes through recognition of a glucose-regulated preproinsulin epitope. J Clin Invest. 2008;118:3390-402.

6. Tang Q, Bluestone JA. Regulatory T-cell physiology and application to treat autoimmunity. Immunol Rev. 2006;212:217-37.

7. Chen W, Bluestone JA, Herold KC. Achieving antigen-specific tolerance in diabetes: regulating specifically. Int Rev Immunol. 2005;24:287-305.

8. Tiegs G, Hentschel J, Wendel A. A T cell-dependent experimental liver injury in mice inducible by concanavalin A. J Clin Invest. 1992;90:196-203.

9. Dienes HP, Drebber U. Pathology of immune-mediated liver injury. Dig Dis. 2010;28:57-62.

10. Kubo N, Narumi S, Kijima H, Mizukami H, Yagihashi S, Hakamada K, Nakane A. Efficacy of adipose tissue-derived mesenchymal stem cells for fulminant hepatitis in mice induced by concanavalin A. J Gastroenterol Hepatol. 2012;27:165-72.

11. Sorensen JO, Buschard K, Brogren $\mathrm{CH}$. The preventive role of type 2 NKT cells in the development of type 1 diabetes. APMIS. 2014;122:167-82.

12. Ford MS, Chen W, Wong S, Li C, Vanama R, Elford AR, Asa SL, Ohashi PS, Zhang L. Peptide-activated double-negative T cells can prevent autoimmune type-1 diabetes development. Eur J Immunol. 2007;37:2234-41.

13. Zhang D, Zhang W, Ng TW, Wang Y, Liu Q, Gorantla V, Lakkis F, Zheng XX. Adoptive cell therapy using antigen-specific CD4-CD8-T regulatory cells to prevent autoimmune diabetes and promote islet allograft survival in NOD mice. Diabetologia. 2011;54:2082-92.

14. Thomson CW, Lee BP, Zhang L. Double-negative regulatory T cells: nonconventional regulators. Immunol Res. 2006;35:163-78.

15. Juvet SC, Zhang L. Double negative regulatory $T$ cells in transplantation and autoimmunity: recent progress and future directions. J Mol Cell Biol. 2012;4:48-58.

16. Duncan B, Nazarov-Stoica C, Surls J, Kehl M, Bona C, Casares S, Brumeanu TD. Double negative (CD3 + 4- 8-) TCR alphabeta splenic cells from young NOD mice provide long-lasting protection against type 1 diabetes. PLoS One. 2010;5:e11427.

17. Zhang D, Yang W, Degauque N, Tian Y, Mikita A, Zheng XX. New differentiation pathway for double-negative regulatory $T$ cells that regulates the magnitude of immune responses. Blood. 2007;109:4071-9.
18. VoelkI S, Gary R, Mackensen A. Characterization of the immunoregulatory function of human TCR-aß+CD4-CD8 - double-negative T cells. Eur J Immunol. 2011;41:739-48.

19. Xia CQ, Chernatynskaya AV, Wasserfall CH, Wan S, Looney BM, Eisenbeis S, Williams J, Clare-Salzler MJ, Atkinson MA. Anti-thymocyte globulin (ATG) differentially depletes naive and memory $T$ cells and permits memorytype regulatory $T$ cells in nonobese diabetic mice. BMC Immunol. 2012;13:70.

20. Asherson GL, Ferluga J, Janossy G. Non-specific cytotoxicity by T cells activated with plant mitogens in vitro and the requirement for plant agents during the killing reaction. Clin Exp Immunol. 1973;15:573-89.

21. D'Acquisto F, Crompton T. CD3+CD4-CD8-(double negative) T cells: Saviours or villains of the immune response? Biochem Pharmacol. 2011;82:333-40.

22. Hillhouse EE, Lesage S. A comprehensive review of the phenotype and function of antigen-specific immunoregulatory double negative T cells. J Autoimmun. 2013;40:58-65.

23. Ji YR, Kim HJ, Bae KB, Lee S, Kim MO, Ryoo ZY. Hepatic serum amyloid A-1 aggravates $T$ cell mediated hepatitis by inducing chemokines via Toll-like receptor 2 in mice. J Biol Chem. 2015;290:12804-11.

24. Bacigalupo A. Antilymphocyte/thymocyte globulin for graft versus host disease prophylaxis: efficacy and side effects. Bone Marrow Transplant 2005;35:225-31.

25. Hardinger KL. Rabbit antithymocyte globulin induction therapy in adult renal transplantation. Pharmacotherapy. 2006;26:1771-83.

26. Shapiro R, Young JB, Milford EL, Trotter JF, Bustami RT, Leichtman AB. Immunosuppression: evolution in practice and trends, 1993-2003. Am J Transplant. 2005;5:874-86

27. Chung DT, Korn T, Richard J, Ruzek M, Kohm AP, Miller S, Nahill S, Oukka M. Anti-thymocyte globulin (ATG) prevents autoimmune encephalomyelitis by expanding myelin antigen-specific Foxp3+ regulatory T cells. Int Immunol. 2007;19:1003-10.

28. Gluckman E, Esperou-Bourdeau H, Baruchel A, Boogaerts M, Briere J, Donadio D, Leverger G, Leporrier M, Reiffers J, Janvier M, et al. A multicenter randomized study comparing cyclosporin-A alone and antithymocyte globulin with prednisone for treatment of severe aplastic anemia. The cooperative group on the treatment of aplastic anemia. J Autoimmun. 1992;5:271-5 (Suppl A)

29. Musso M, Porretto F, Crescimanno A, Bondi F, Polizzi V, Scalone R. Intense immunosuppressive therapy followed by autologous peripheral blood selected progenitor cell reinfusion for severe autoimmune disease. Am J Hematol. 2001;66:75-9.

30. Saudek F, Havrdova T, Boucek P, Karasova L, Novota P, Skibova J. Polyclonal anti-T-cell therapy for type 1 diabetes mellitus of recent onset. Rev Diabet Stud. 2004;1:80-8.

31. van de Linde P, Tysma OM, Medema JP, Hale G, Waldmann H, Roelen DL, Roep BO. Mechanisms of antibody immunotherapy on clonal islet reactive T cells. Hum Immunol. 2006;67:264-73.

32. Ide LM, Gangadharan B, Chiang KY, Doering CB, Spencer HT. Hematopoietic stem-cell gene therapy of hemophilia A incorporating a porcine factor VIII transgene and nonmyeloablative conditioning regimens. Blood. 2007;110:2855-63.

33. Harada M, Makino S. Suppression of overt diabetes in NOD mice by anti-thymocyte serum or anti-Thy 1, 2 antibody. Jikken Dobutsu. 1986;35:501-4.

34. Gitelman SE, Gottlieb PA, Rigby MR, Felner El, Willi SM, Fisher LK, Moran A, Gottschalk M, Moore WV, Pinckney A, et al. Antithymocyte globulin treatment for patients with recent-onset type 1 diabetes: 12-month results of a randomised, placebo-controlled, phase 2 trial. Lancet Diabetes Endocrinol. 2013;1:306-16.

35. Kwon HJ, Won YS, Park O, Feng D, Gao B. Opposing effects of prednisolone treatment on T/NKT cell- and hepatotoxin-mediated hepatitis in mice. Hepatology. 2014;59:1094-106.

36. Hillhouse EE, Delisle JS, Lesage S. Immunoregulatory CD4(-)CD8(-) T cells as a potential therapeutic tool for transplantation, autoimmunity, and cancer. Front Immunol. 2013;4:6.

37. Ueha S, Yoneyama H, Hontsu S, Kurachi M, Kitabatake M, Abe J, Yoshie O, Shibayama S, Sugiyama T, Matsushima K. CCR7 mediates the migration of Foxp3+ regulatory T cells to the paracortical areas of peripheral lymph nodes through high endothelial venules. J Leukoc Biol. 2007;82:1230-8. 